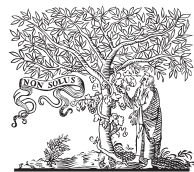

the Journal of

Molecular

ELSEVIER

Diagnostics

See related article on page 805

jmdjournal.org

\title{
COMMENTARY
}

\section{Transitioning T-Cell Clonality Testing to High-Throughput Sequencing}

Timothy C. Greiner, ${ }^{*}$ Adam Bagg, ${ }^{\dagger}$ and Anton W. Langerak

From the Department of Pathology and Microbiology, * University of Nebraska Medical Center, Omaha, Nebraska; the Division of Hematopathology, Department of Pathology and Laboratory Medicine, Hospital of the University of Pennsylvania, Philadelphia, Pennsylvania; and the Laboratory of Medical Immunology, ${ }^{\ddagger}$ Department of Immunology, Erasmus University Medical Center, Rotterdam, the Netherlands

The laboratory community continues to work on the implementation of high-throughput sequencing (HTS) for use in analyzing T-cell clonality at the level of T-cell receptor $\gamma$ gene (TRG) rearrangements, and the latest installment is the validation study reported in this issue of The Journal of Molecular Diagnostics. ${ }^{1}$ To the best of our knowledge, the first clinical-validation study on TRG-based clonality by HTS, was published in 2014 by Schumacher et al. ${ }^{2}$ They compared an HTS assay with conventional capillary electrophoresis. ${ }^{2}$ A commentary by one of the authors at that time listed issues that should be included in future validations of HTS assays for clonality ${ }^{3}$ : proportional representation by primers of all of the clinically important TRG genes, equal amplification efficiency of the primers, using a software pipeline that accurately identifies the TRG variable and joining genes, and defining the criteria for a clonal result. ${ }^{3}$

\section{HTS for TRG: Then and Now}

In 2014, Schumacher et al used published TRG primers, ${ }^{4}$ added adaptors, and performed sequencing on two instruments, the Ion PGM System (Thermo Fisher Scientific, Waltham, MA) and the Illumina MiSeq instrument (Illumina, San Diego, CA). ${ }^{2}$ By contrast, Ho et al $^{1}$ used a proprietary LymphoTrack kit of TRG primers (Invivoscribe, San Diego, CA) and performed HTS sequencing using the MiSeq instrument. Schumacher et al used primers with established coverage of all clinically relevant TRG genes ${ }^{4}$ in their HTS analysis of 48 samples, and compared them to capillary electrophoresis (CE) using the same primer set. ${ }^{2}$ By contrast, Ho et $\mathrm{al}^{1}$ used a set of BIOMED primers for the CE that did not include the $\mathrm{J} \gamma \mathrm{P}$ primer, which is different from the HTS LymphoTrack kit method (Invivoscribe, San Diego, CA) that contains a complete set of primers including $\mathrm{J} \gamma \mathrm{P}$. This issue was identified in a commentary in $2014,{ }^{3}$ which stated that all relevant primers should be used in TRG HTS analysis so that comparisons for validation can be performed head to head. The need for a complete primer set, including $\mathrm{J} \gamma \mathrm{P}$, to avoid false-negative results in a TRG clonality assay has been previously established.

\section{Compliance with General Bioinformatic Recommendations}

Ho et al $^{1}$ studied 101 specimens, which exceeded the minimum of 59 specimens recommended in the guideline on HTS bioinformatics from the Association for Molecular Pathology. ${ }^{6}$ By contrast, Schumacher et $\mathrm{al}^{2}$ studied only 48 clinical specimens. From a biology perspective, an analysis of at least 50 specimens is required for the detection of at least one of the rare TRG rearrangements utilizing the $\mathrm{J} \gamma \mathrm{P}$ gene, which has a frequency rate of $3 \%$, and the $\mathrm{V} \gamma 11$ gene, which has a frequency rate of $4 \% .^{5}$ The Association for Molecular Pathology and the College of American Pathologists recommend that clinical laboratories validate their bioinformatics pipeline for HTS. ${ }^{7}$ It is challenging to use a second pipeline to independently validate the use of customdesigned software, like the TCRDriver package, ${ }^{2}$ or proprietary software, like the LymphoTrack system, ${ }^{1}$ to

Accepted for publication May 17, 2021

Disclosures: T.C.G. has previously consulted with Invivoscribe on the construction of a TRG assay and provision of specimens for validation of a TRG assay.

Address correspondence to Timothy C. Greiner, M.D., Department of Pathology and Microbiology, 983135 University of Nebraska Medical Center, Omaha, NE 68198. E-mail: tgreiner@unmc.edu 
verify the accuracy of variable and joining region gene identification.

\section{TRG Testing with HTS versus CE}

As shown by Ho et al, ${ }^{1}$ HTS has numerous advantages over CE. These include the requirement of lesser amounts of DNA, a lower frequency of false positives, and increased objectivity. Ho et al $^{1}$ also found that peaks of identical size-defined as an equal number of base pairs in the amplified products, as detected using $\mathrm{CE}-\mathrm{do}$ not always imply clonal identity at the sequence level, as was previously reported. $^{8}$

One other important concept in the article by $\mathrm{Ho} \mathrm{et}^{\mathrm{al}}{ }^{1}$ is that some of the discordant results between the CE- and HTS-based approaches appeared to be the result of falsepositive findings on $\mathrm{CE}$ due to a lack of background competition using the two-tube CE system. In a two-tube $\mathrm{CE}$ assay, the competitive amplification of the primers is spread out in multiple distributions, whereas in the one-tube assay, all of the primers compete against each other for amplification. ${ }^{9}$ This interpretation was (partly) corroborated by the lack of clonal peaks in a one-tube $\mathrm{CE}$ assay in some samples tested by Ho et al. ${ }^{1}$ The findings from a two-tube $\mathrm{CE}$ assay are also more difficult to interpret than those from a one-tube $\mathrm{CE}$ assay. A one-tube $\mathrm{CE}$ assay precludes the need for an evaluation of isolated fluorescence signals in more than one distribution, as is the case in the two-tube TRG CE assay. These observations reinforce the need to move away from multitube CE systems for one target as recommended by Cushman-Vokoun et al ${ }^{9}$ and as recently discussed by Armand et al. ${ }^{10}$

The one-tube system is also the preferred design for a TRG HTS assay, first described by Schumacher et al. ${ }^{2}$ In a single-tube HTS system, only a single calculation is required for defining a clonal result. Whether the clonal read percentage (minimum $4.5 \%$ ) should be four-fold higher than the polyclonal background ${ }^{2}$ or the clonal read percentage (minimum 2.5\%) should be five-fold higher than the fourth most abundant clonotype as appropriate criteria for clonality remains to be determined.

\section{Incorporation of TRG Testing by HTS in Clinical Laboratories}

The progress in adoption has been slow for a number of reasons, including the relatively long turnaround time of 3 to 7 days for sequencing and analysis and the increased cost of HTS compared to CE. Therefore, most laboratories continue to use CE. However, as shorter run times are enabled and as costs come down, HTS will become more competitive with $\mathrm{CE}$, leading to the continued growth of HTS. Additionally, HTS is becoming the central workflow for multiple molecular assays such as somatic variant detection, which results in a more natural transition to
$\mathrm{Ig} / \mathrm{T}$-cell receptor HTS assays through combined HTS runs. New instruments, which have a more flexible workflow than prior incantations, may facilitate this transition.

\section{Other Developments in the Past Decade}

For analysis of both TRG and TRB by HTS, several companies and collaborative groups have developed kits and methods applicable to DNA and/or RNA. Some amplicons are short enough to be sequenced in paraffin-embedded tissue, like in the methods used in both studies. ${ }^{1,2} \mathrm{Com}-$ parisons between these relatively new kits and methods should provide useful data for assessment by the laboratory community.

\section{Current and Future Needs of the Laboratory Community}

Molecular genetic pathology laboratories would benefit from guidelines on the validation of both IG and T-cell receptor HTS clonality assays in a scientifically and economically sound framework. CE, while still quite clinically useful, has limitations in being the gold standard for comparison. Some questions remain to be resolved. Examples include: i) Is a single HTS TRG assay adequate, or should the HTS assay be performed in duplicate, as many laboratories do now with $\mathrm{CE}$, to obtain reproducible results?; ii) What percent of a unique TRG sequence read should define a clonal result?; and iii) What is the role of a TRB HTS assay in resolving ambiguous TRG HTS results? Recognizing this need, The Association for Molecular Pathology has established a NGS Utility for Assessment of T/ B-cell Clonality working group, chaired by Dr. David Viswanatha, to address these issues. In parallel, analogous to published guidelines on $\mathrm{CE},{ }^{11}$ the EuroClonality-NGS working group chaired by one of the authors (Dr. A.W. Langerak) is also developing guidelines on $\mathrm{Ig} / \mathrm{T}$-cell receptor HTS testing, which will be based on data from multicenter studies, such as the Ig biological validation study (Van den Brand, unpublished data). The Journal of Molecular Diagnostics readership is encouraged to look out for these upcoming important documents.

\section{References}

1. Ho CC, Tung JK, Zehnder JL, Zhang BM: Validation of a nextgeneration sequencing-based T-cell receptor gamma gene rearrangement diagnostic assay: transitioning from capillary electrophoresis to next-generation sequencing. J Mol Diagn 2021, 23:805-815

2. Schumacher JA, Duncavage EJ, Mosbruger TL, Szankasi PM, Kelley TW: A comparison of deep sequencing of TCRG rearrangements vs traditional capillary electrophoresis for assessment of clonality in T-cell lymphoproliferative disorders. Am J Clin Pathol 2014, 141:348-359

3. Greiner TC: Clinical use of next-generation sequencing of TRG gene rearrangements has arrived. Am J Clin Pathol 2014, 141:302-304 
4. Greiner TC, Rubocki RJ: Effectiveness of capillary electrophoresis using florescent-labeled primer in detecting T-cell receptor gamma gene rearrangements. J Mol Diagn 2002, 4:137-143

5. Lawnicki LC, Rubocki RJ, Chan WC, Lytle DM, Greiner TC: The distribution of gene segments in T-cell receptor [gamma] gene rearrangements demonstrates the need for multiple primer sets. J Mol Diagn 2003, 5:82-87

6. Jennings LJ, Arcila ME, Corless C, Kamel-Reid S, Lubin IM, Pfeifer J, Temple-Smolkin RL, Voelkerding KV, Nikiforova MN: Guidelines for validation of next-generation sequencing-based oncology panels. J Mol Diagn 2017, 19:341-365

7. Roy S, Coldren C, Karumamurthy A, Kip NS, Klee EW, Lincoln SE, Leon A, Pullambhatla M, Temple-Smolkin RL, Voelkerding KV, Wang C, Carter AB: Standards and guidelines for validating nextgeneration sequencing bioinformatics pipelines: a joint recommendation of the association for molecular pathology and the College of American Pathologists. J Mol Diagn 2018, 20:4-27

8. Rea B, Haun P, Emerson R, Vignali M, Farooqi M, Samimi S, Elenitsas R, Kirsch I, Bagg A: Role of high-throughput sequencing in the diagnosis of cutaneous T-cell lymphoma. J Clin Pathol 2018, 71 $814-820$

9. Cushman-Vokoun AM, Connealy S, Greiner TC: Assay design affects the interpretation of $\mathrm{T}$-cell receptor gamma gene rearrangements: comparison of the performance of a one-tube assay with the BIOMED2-based TCRG gene clonality assay. J Mol Diagn 2010, 12:787-796

10. Armand M, Derrieux C, Beldjord K, Wabeke T, Lenze D, Boone E, Bruggemann M, Evans PAS, Gameiro P, Hummel M, Villarese P, Groenen PJTA, Langerak AW, Macintyre EA, Davi F: A new and simple TRG multiplex PCR assay for assessment of T-cell clonality: a comparative study from the EuroClonality Consortium. Hemasphere 2019, 3:e255

11. Langerak AW, Groenen PJ, Brüggemann M, Beldjord K, Bellan C, Bonello L, Boone E, Carter GI, Catherwood M, Davi F, DelfauLarue MH, Diss T, Evans PA, Gameiro P, Garcia Sanz R, Gonzalez D, Grand D, Håkansson A, Hummel M, Liu H, Lombardia L, Macintyre EA, Milner BJ, Montes-Moreno S, Schuuring E, Spaargaren M, Hodges E, van Dongen JJ: EuroClonality/BIOMED-2 guidelines for interpretation and reporting of $\mathrm{Ig} / \mathrm{TCR}$ clonality testing in suspected lymphoproliferations. Leukemia 2012, 26:2159-2171 